\title{
Effects of Aquatic Proprioceptive Neuromuscular Facilitation Pattern Exercise on Balance, Gait ability and Depression in Patients with Chronic Stroke
}

\author{
Dong-Kyu Lee', Tae-Yeun Hwang ${ }^{2}$ \\ 'Department of Physical Therapy, Sunhan Hospital, Gwangju; '2Department of Physical Therapy, Chunnam Techno University, Gekseong, Korea
}

Purpose: This study examined the effects of aquatic proprioceptive neuromuscular facilitation pattern exercise on the balance, gait ability, and depression in patients with chronic stroke.

Methods: Thirty patients with chronic stroke were assigned randomly to an experimental $(n=15)$ or control $(n=15)$ group. The experimental group performed aquatic proprioceptive neuromuscular facilitation pattern exercise. The control group performed ground proprioceptive neuromuscular facilitation pattern exercise. Training was conducted once a day for 30 minutes, five days per week for six weeks. The balance ability was measured using the Berg balance scale. The gait ability was measured using the 10 Meter walk test. Depression was measured using the Beck depression inventory.

Results: As a result of a comparison within groups, the experimental and control group showed a significant difference for balance, gait ability, and depression after the experiment $(p<0.05)$. In a comparison between the two groups, the experimental group, in which aquatic proprioceptive neuromuscular facilitation pattern exercise was applied, showed more significant changes in balance, gait ability, and depression than the control group $(\mathrm{p}<0.05)$.

Conclusion: Based on these results, aquatic proprioceptive neuromuscular facilitation pattern exercise effectively improved the balance, gait ability and depression in patients with chronic stroke.

Keywords: Aquatic proprioceptive neuromuscular facilitation, Balance, Gait, Depression

\section{서 론}

뇌 병변 장애 중 하나인 뇌졸중은 뇌에 공급되는 혈류가 차단된 허혈 성 뇌졸중(ischemic stroke)과 뇌 조직의 출혈로 인한 출혈성 뇌졸중 (hemorrhagic stroke)로 인하여 운동 신경과 감각 신경 손상을 동반하 면서 생기는 질병이다. 뇌졸중 증상은 손상 위치와 크기 및 원인에 따라 다양하며 마비와 실조, 시각 장애, 인지 장애, 운동 장애, 감각 결 손 및 기억력 장애 등과 같은 신경학적 증상을 유발하고 있으며 ${ }^{2}$ 운 동과 감각 기능 장애로 신체적 활동에 제한을 받게 되며 움직임이나 기능을 회복하지 못해 영구적인 장애를 가지고 살아간다. 뇌졸중 환 자 대부분은 시상면에서 신체의 한쪽이 마비되는 편마비는 신체의 동요가 커지고 신체 내 질량 중심은 비마비측으로 편중 되어 하지의 체중 분포가 비대칭적으로 나타나며 기립 자세와 균형 및 보행 능력

Received Jul 4, 2019 Revised Aug 16, 2019

Accepted Aug 19, 2019

Corresponding author Tae-Yeun Hwang

E-mail delta21kr@hanmail.net

\section{의 장애가 나타난다.3.4}

균형(balance)이란 자세 조절(postural control)이라고도 하며 기저면 (base of support)과 관련하여 중력 중심 이동을 조절하는 능력으로 뇌 졸중 환자들의 대부분은 신체의 비대칭적인 자세를 갖게 되며 정상 인에 비하여 기립 시 자세 동요가 커지면서 자세 조절과 균형 능력을 감소시킨다.5, 균형 능력의 저하는 뇌졸중 환자들의 정상적인 움직임 과 보행에 어려움을 겪게 되며 일상생활동작에도 나뺀 영향을 주고 있으며 장기간에 걸쳐 일상생활동작을 수행하지 못하면 무력감과 심각한 우울에 빠지기 쉽다. ${ }^{8}$

뇌졸중 환자에게 나타나는 병변과 관련된 고위 중추의 통합 기능 과 운동 감각 통로의 손상으로 나타나는 보행 능력 장애는 비활동과 비사용에 의해 나타난다. 9 뇌졸중 환자들의 $75 \%$ 는 독립 보행이 가능 하지만 그 중에서 $50 \%$ 는 보행 능력 장애를 가지고 일상생활동작을 
하게 되는데 ${ }^{9,10}$ Bohannon 등 10 은 뇌졸중 환자의 독립적인 일상생활동 작 수행 능력 저하와 움직임 시 환경 요소에 대한 두려움의 원인이 보 행 능력의 감소였다고 보고되고 있다.

뇌졸중은 발병 후 생존하더라도 중추신경계 기능 장애로 환자의 $73 \%$ 에서 영구적인 장애가 남기 때문에 적절한 치료가 매우 중요하 다."1 신체적 기능 손상을 회복시키는데 중점을 두고 있는 방법 중 하 나인 고유수용성신경근촉진법은 고유수용기를 자극하여 신경근 반 응을 촉진시키거나 혹은 증진시키는 방법으로 ${ }^{12}$ 뇌졸중 환자에게 적 용하여 기능적 활동을 훈련시키고 여러 가지 형태의 손상을 방지하 기 위해 적용되며 뇌졸중 환자 치료에서 손상을 개선시키기 위한 목 적으로 점진적 저항 운동의 대안으로 사용하고 있다. ${ }^{12,13}$ 고유수용성 신경근촉진법은 대각선과 나선형 패턴으로 이루어져 있으며 근육들 의 작용 방향과 일치하기 때문에 단일 방향과 단일 면으로 실시되는 운동 보다 근 수행력을 증진시키는데 효과적이다. ${ }^{14} \mathrm{Lim}^{15}$ 과 $\mathrm{Kim}$ 과 $\mathrm{Kim}^{16}$ 의 연구에서 뇌졸중 환자에게 고유수용성신경근 패턴 운동을 적용한 결과 균형과 보행 능력 향상에 효과적임을 증명하였다.

최근에는 수중운동을 포함하여 다양한 환경 조건을 이용한 치료 가 실시되어지고 있다. ${ }^{17}$ 뇌졸중 환자를 치료하는 환경은 지상보다 수 중에서 안전하고 부상 없이 수행 할 수 있으며 지상에서 능동적으로 불가능한 다양한 운동 패턴을 조기에 경험 할 수 있게 해주며 낙상에 대한 두려움도 감소시킬 수 있다. ${ }^{1718}$ 수중운동에서 부력은 중력의 영 향을 감소시켜 지상에서 중력에 의해 사용이 제한되었던 근육과 관 절에 부담을 덜어주고 체중 부하를 할 수 없는 환자들이 적은 힘으로 움직임이 가능하도록 도와주며 뇌졸중 환자의 마비측 사용 빈도를 높여 좀 더 고른 신체 발달을 유도 할 수 있도록 보조해 준다. ${ }^{17,19}$ Choi 과 Yoon ${ }^{20}$ 는 수중회전조절운동이 균형능력 향상에 긍정적인 영향을 미친다고 하였으며, $\operatorname{Kim}$ 등 $^{21}$ 은 뇌졸중 환자에게 수중운동을 적용한 결과 균형 능력 향상과 우울 감소에 영향을 미친다고 보고하였다.

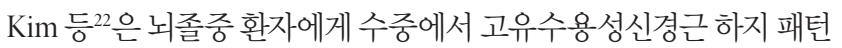
운동이 균형 능력과 일상생활활동에 효과적이라고 보고되고 있다. 또한 수중고유수용성신경근촉진법을 이용한 협응 운동이 뇌졸중 환자의 균형과 보행 능력 향상에 긍정적인 효과를 미친다고 하였다.23

현재까지 수중운동은 많은 장점을 가지고 있음에도 불구하고 뇌 졸중 환자의 치료는 지상에서 이루어지고 있으며 수중운동 효과는 많이 입증되고 있지만 동일한 과제를 이용하여 지상운동에 비해 효 과적임을 주장하는 연구와 수중 고유수용성신경근촉진법 패턴을 이용한 치료 방법이 효과적임을 주장하는 연구는 미흡한 상태이다. 이에 본 연구는 수중과 지상에서 고유수용성신경근촉진법 패턴을 만성 뇌졸중 환자를 대상으로 실시하여 균형과 보행 및 일상생활동 작을 비교하여 수중에서 고유수용성신경근촉진법 패턴 운동의 효 과에 대한 근거를 제시하고 질적 향상에 기여하고자 한다.

\section{연구 방법}

\section{1. 연구대상}

본 연구는 컴퓨터 뇌 단층화 촬영(computed tomography)과 자기공명 영상(magnetic resonance imaging) 소견상 신경외과 의사에게 뇌졸중 으로 진단 받고 입원하여 물리치료를 받는 만성 뇌졸중 환자 30 명을 대상으로 눈 감은 상태에서 제비 뽑기를 이용하여 수중고유수용성 신경근촉진법 패턴 운동을 실시하는 실험군 15 명과 지상고유수용성 신경근촉진법 패턴 운동을 실시하는 대조군 15 명으로 무작위 배정 하였다. 대상자 선정 조건은 뇌졸중으로 인한 편마비가 발병된지 6개 월 이상 되었으며 한국형 간이 정신 상태 판별검사(Mini-mental state examination-korea version, MMSE-K) 점수가 24점 이상인 자로 시야결 손과 전정기관에 이상이 없으며 체간과 양측 하지에 정형외과적 질 환이 없으며 물에 대한 두려움이 없고 독립적으로 기립 자세를 30 초 이상 지속할 수 있으며 실내에서 타인의 도움 없이 $10 \mathrm{~m}$ 보행이 가능 한 자로 선정하였다. 연구 대상자의 일반적인 특성은 다음과 같다 (Table 1). 연구대상자들에게 실험을 실시하기 전에 연구의 목적과 절 차에 대하여 설명을 하였으며 참여한 대상자들은 모두 동의를 하였 으며 대구대학교 생명윤리위원회에서 승인을 받은 후 실험을 진행하 였다(승인: 1040621-201611-HR-018-02).

\section{2. 실험방법}

\section{1) 수중고유수용성신경근촉진법 패턴 운동}

실험군은 수중고유수용성신경근촉진법 패턴 운동을 30 분 적용하였 다. 수중 환경은 수심 $1 \mathrm{~m}$ 에서 물 온도 $32 \sim 34^{\circ} \mathrm{C}$ 로 높게 유지하여 환자 를 낮은 온도에서 추위에 떠는 것을 방지함으로써 갑작스런 근 긴장 을 방지하도록 하였다. 운동을 실시하기 전에 물리치료사가 먼저 시범 을 보여주어 운동 방법을 빠르게 이해하고 수행 할 수 있도록 하였다. 본 운동을 실시하기 전에 실험 대상자는 요추 5 번과 천추 1 번 사이에 부력 보조 기구인 링 튜브와 목에 튜브를 착용하고 수중에서 바로 누 운 자세에서 율동적 개시 기법(rhythmic initiation)을 이용하여 고유수

Table 1. General characteristics of study subjects

\begin{tabular}{lccc}
\hline & EG $(n=15)$ & CG $(n=15)$ & $p$ \\
\hline Gender (M/F) & $8 / 7$ & $7 / 8$ & \\
Paretic side (left/right) & $6 / 9$ & $7 / 8$ & \\
Age (year) & $57.80 \pm 8.98$ & $59.66 \pm 7.49$ & 0.542 \\
Height (cm) & $170.13 \pm 8.01$ & $168.86 \pm 6.88$ & 0.641 \\
Weight (kg) & $68.13 \pm 8.21$ & $65.13 \pm 8.08$ & 0.324 \\
Duration (months) & $14.26 \pm 1.70$ & $13.06 \pm 1.83$ & 0.072 \\
MMSE-K (score) & $26.60 \pm 0.82$ & $27.13 \pm 0.83$ & 0.091 \\
\hline
\end{tabular}

Values are presented as mean \pm standard deviation.

EG: experimental group, CG: control group. 
용성신경근촉진법 패턴 운동을 실시하였다(Table 2). 율동적 개시 기 법은 수동적 운동에서 시작하고 능동적 저항 운동으로 진행하였다. 각 패턴마다 1 세트 당 10 회씩 총 3 세트를 실시하였고 숙련 정도에 따 라 세트 수를 조절하거나 바로 다음 패턴 운동을 진행하였다.

\section{2) 지상고유수용성신경근촉진법 패턴 운동}

대조군은 지상고유수용성신경근촉진법 패턴 운동을 30 분 적용하였 다. 운동을 실시하기 전에 물리치료사가 먼저 시범을 보여주어 운동 방법을 빠르게 이해하고 수행 할 수 있도록 하였다. 테이블에 바로 누 운 자세에서 율동적 개시 기법(rhythmic initiation)을 이용하여 고유 수용성신경근촉진법 패턴 운동을 실시하였다(Table 2). 율동적 개시 기법은 수동적 운동에서 시작하고 능동적 저항 운동으로 진행하였 다. 각 패턴마다 1 세트 당 10 회씩 총 3 세트를 실시하였고 숙련 정도에 따라 세트 수를 조절하거나 바로 다음 패턴 운동을 진행하였다.

\section{3) 측정도구}

(1) 균형 능력 측정

균형 능력은 버그균형척도(berg’s balance scale, BBS)를 이용하여 측정 하였다. BBS는 14 개의 항목으로 앉기, 서기, 자세 변화의 3 개의 영역을 최소 0 점에서 최대 4 점으로 총점은 56 점으로 점수가 높을수록 좋은 균형 능력을 가지고 있다고 평가한다. 버그균형척도의 측정자내 신뢰 도는 $r=0.99$ 이고 측정자간 신뢰도는 $r=0.98$ 로 높은 신뢰도를 가진 평 가 도구이다.24

\section{(2) 보행 능력 측정}

보행 능력은 $10 \mathrm{~m}$ 보행 검사(10 meter walk test, $10 \mathrm{MWT})$ 를 이용하여

Table 2. Proprioceptive neuromuscular facilitation pattern exercise

\begin{tabular}{|c|c|c|}
\hline \multicolumn{3}{|r|}{ Exercise program } \\
\hline \multicolumn{2}{|c|}{ Warm up (5 min) } & Stretching \\
\hline \multirow[t]{8}{*}{$\begin{array}{l}\text { Exercise } \\
\text { (30 min) }\end{array}$} & Pattern 1 & $\begin{array}{l}\text { Flexion-adduction-external rotation with knee flexion } \\
\text { isotonic }\end{array}$ \\
\hline & & $\begin{array}{l}\text { Extension-adduction-external rotation with extened } \\
\text { knee isometric }\end{array}$ \\
\hline & Pattern 2 & $\begin{array}{l}\text { Flexion-abduction-internal rotation with knee flexion } \\
\text { isotonic }\end{array}$ \\
\hline & & $\begin{array}{l}\text { Extension-adduction-internal rotation with extened } \\
\text { knee isometric }\end{array}$ \\
\hline & Pattern 3 & $\begin{array}{l}\text { Flexion-adduction-external rotation knee and trunk } \\
\text { flexion isotonic }\end{array}$ \\
\hline & Pattern 4 & $\begin{array}{l}\text { Extension-abduction-internal rotation knee and trunk } \\
\text { extension isotonic }\end{array}$ \\
\hline & Pattern 5 & $\begin{array}{l}\text { Flexion-abduction-internal rotation knee and trunk flex- } \\
\text { ion isotonic }\end{array}$ \\
\hline & Pattern 6 & $\begin{array}{l}\text { Extension-adduction-external rotation knee and trunk } \\
\text { extension isotonic }\end{array}$ \\
\hline \multicolumn{2}{|c|}{ Cool down (5 min) } & Stretching \\
\hline
\end{tabular}

측정하였다. $10 \mathrm{MWT}$ 는 총 $14 \mathrm{~m}$ 직선거리를 설정하여 가속과 감속구 간에 대한 오차를 줄이기 위하여 시작과 끝 범위 $2 \mathrm{~m}$ 거리를 제외한 $10 \mathrm{~m}$ 거리를 걷는데 걸리는 시간을 측정하였다. 검사 방법은 측정 시 간이 길수록 보행 능력이 떨어짐을 의미한다. 측정 오차를 최소화하 기 위해 3 회 반복 측정 하여 평균값을 사용하였다. $10 \mathrm{~m}$ 보행 검사의 측정자 간 신뢰도와 측정자 내 신뢰도는 $r=.89$ 에서 $r=1.00$ 으로 높은 신뢰도를 가지고 있다. ${ }^{25}$

\section{(3) 우울 정도 측정}

우울 정도는 설문지 형식의 Beck 우울 척도(beck depression inventory, $\mathrm{BDI}$ 를 이용하여 측정하였다. $\mathrm{BDI}$ 는 21 개 문항으로 정서적, 인지적, 동기적, 생리적 그리고 다른 증상들이 포함되어 각 문항마다 0-3점까 지의 4점 Likert 척도로 총점 범위는 63점으로 점수화하는 방법은 문 항의 점수를 모두 더한 총점을 사용하며 최소 0 점에서 최대 63점이 다. 총점 0-9점은 우울하지 않은 상태, 10-15점은 가벼운 우울 상태, 16-23점은 중한 우울 상태, 24-63점은 심한 우울 상태로 높은 점수일 수록 우울이 심한 것이다. Beck 우울 척도 신뢰도는 Hanh 등 26 연구에 서 정상인 집단에서 Cronbach's $\alpha=.89$, 우울 집단에서는 Cronbach's $\alpha$ $=.94$ 이었다.

\section{3. 자료분석}

본 연구를 위한 자료처리 방법은 Window용 통계프로그램 SPSS 19.0 software (SPSS Inc, Chicago, USA)을 이용하여 통계 처리하였다. 연구 대상자의 일반적인 특성은 기술 통계를 사용하였으며 일반적 특성에 대한 차이는 독립표본 t-검정(independent t-test)을 실시하였다. 샤피 로-윌크(shapiro-wilk) 검정 방법으로 정규성 검정을 실시하였으며 모 든 변수가 정규 분포하였다. 실험 전과 후의 집단 내 균형과 보행 능력 및 우울 정도 변화를 비교하기 위하여 대응표본 t-검정(paired t-test)을 실시하였다. 실험군과 대조군의 집단 간 전, 후 변화량 차이를 비교하 기 위해 독립표본 t-검정(independent t-test)으로 검정하였다. 모든 통 계학적 유의수준은 $\alpha=0.05$ 설정하였다.

\section{결 과}

\section{1. 균형 능력 변화 비교}

균형 능력 변화를 알아보기 위하여 BBS를 사용하여 측정한 결과는 다음과 같다(Table 3). 실험군은 실험 전 $41.06 \pm 2.01$ 에서 실험 후 43.06 \pm 1.57 으로 유의한 차이가 있었고 $(\mathrm{p}<0.05)$, 대조군은 실험 전 $42.33 \pm$ 1.71 에서 실험 후 $43.66 \pm 1.87$ 으로 유의한 차이가 있었다 $(\mathrm{p}<0.05)$. 실험 군과 대조군의 전, 후 차이를 통한 집단 간 비교에서 실험군이 대조군 에 비하여 BBS가 유의하게 개선되었다( $<<0.05)(T a b l e ~ 4)$. 
Table 3. The comparison of variable on pre and post in inner-group

\begin{tabular}{lccccc}
\hline & Group & Pre & Post & t & p \\
\hline BBS (score) & EG & $41.06 \pm 2.01$ & $43.06 \pm 1.57$ & -4.971 & $0.000^{*}$ \\
& CG & $42.33 \pm 1.71$ & $43.66 \pm 1.87$ & -2.428 & $0.029^{*}$ \\
10MWT (sec) & EG & $19.67 \pm 2.17$ & $16.86 \pm 1.31$ & 5.714 & $0.000^{*}$ \\
& CG & $18.13 \pm 1.34$ & $16.74 \pm 1.78$ & 3.091 & $0.008^{*}$ \\
BDI (score) & EG & $22.26 \pm 1.33$ & $14.93 \pm 1.90$ & 9.410 & $0.000^{*}$ \\
& CG & $20.60 \pm 1.63$ & $17.33 \pm 1.39$ & 7.062 & $0.000^{*}$
\end{tabular}

Values are presented as mean \pm standard deviation.

${ }^{*} \mathrm{p}<0.05$, EG: experimental group, CG: control group, BBS: Berg balance scale, 10MWT: 10 meter walk test, BDI: Beck depression inventory.

\section{2. 보행 능력 변화 비교}

보행 능력 변화를 알아보기 위하여 $10 \mathrm{MWT}$ 를 사용하여 측정한 결 과는 다음과 같다(Table 3). 실험군은 실험 전 $19.67 \pm 2.17$ 에서 실험 후 $16.86 \pm 1.31$ 으로 유의한 차이가 있었고 $(\mathrm{p}<0.05)$, 대조군은 실험 전 18.13 \pm 1.34 에서 실험 후 $16.74 \pm 1.78$ 으로 유의한 차이가 있었다 $(\mathrm{p}<0.05)$. 실 험군과 대조군의 전, 후 차이를 통한 집단 간 비교에서 실험군이 대조 군에 비하여 10MWT가 유의하게 개선되었다(p<0.05)(Table 4).

\section{3. 우울 정도 변화 비교}

우울 정도 변화를 알아보기 위하여 $\mathrm{BDI}$ 를 사용하여 측정한 결과는 다음과 같다(Table 3). 실험군은 실험 전 $22.26 \pm 1.33$ 에서 실험 후 14.93 \pm 1.90 으로 유의한 차이가 있었고 $(\mathrm{p}<0.05)$, 대조군은 실험 전 $20.60 \pm$ 1.63 에서 실험 후 $17.33 \pm 1.39$ 으로 유의한 차이가 있었다 $(\mathrm{p}<0.05)$. 실험 군과 대조군의 전 후 차이를 통한 집단 간 비교에서 실험군이 대조군 에 비하여 BDI가 유의하게 개선되었다( $<<0.05)(T a b l e 4)$.

\section{고 찰}

본 연구의 목적은 수중고유수용성신경근촉진법 패턴 운동을 만성 뇌졸중 환자에게 적용한 결과 균형과 보행 능력 및 우울 정도 개선에 미치는 효과를 알아보기 위하여 시행되었으며 그 결과 균형과 보행 능력 및 우울 정도 개선에 긍정적인 영향을 미쳤다.

뇌졸중 환자의 운동과 감각 장애는 선택적 근육 활동과 운동 조절 능력 감소와체중지지 능력 및 균형 능력 저하가 나타나며 27 독립적인 일상생활동작 수행에 어려움을 준다. 뇌졸중 환자의 치료에서 균형 능력 증진은 올바른 일상생활동작을 위하여 매우 중요하다. Park 등 ${ }^{28}$ 의 연구에서 시각을 이용한 고유수용성신경근촉진법 패턴 운동이 균형 능력 향상에 유의한 차이를 나타났으며 Sharma과 Kaur ${ }^{29}$ 은 뇌 졸중 환자에게 골반 패턴을 이용한 고유수용성신경근촉진법의 안 정화 운동이 균형 능력 향상을 나타내었고 본 연구 결과와 유사하게 나타났다. 하지 근력 강화 운동은 균형 능력을 증진시키기 위한 운동
Table 4. The comparison of changes in variables between group

\begin{tabular}{lcccc}
\hline & $\mathrm{EG}$ & $\mathrm{CG}$ & $\mathrm{t}$ & $\mathrm{p}$ \\
\hline BBS (score) & $2.00 \pm 1.55$ & $1.33 \pm 2.12$ & 0.979 & $0.039^{*}$ \\
10MWT (sec) & $-2.81 \pm 1.90$ & $-1.38 \pm 1.74$ & -2.137 & $0.041^{*}$ \\
BDI (score) & $-7.33 \pm 2.28$ & $-3.26 \pm 1.79$ & -5.419 & $0.000^{*}$
\end{tabular}

Values are presented as mean \pm standard deviation.

${ }^{*} \mathrm{p}<0.05$, EG: experimental group, CG: control group, BBS: Berg balance scale, 10MWT: 10 meter walk test, BDI: Beck depression inventory.

방법 중 하나이며 ${ }^{30}$ 고유수용성신경근촉진법의 대각선 움직임은 근 육의 수축 방향과 일치하기 때문에 단일 방향과 면으로 운동을 하는 것보다 효과적인 하지 근력 강화 운동을 할 수 있다고 보고되고 있 다. ${ }^{14}$ 고유수용성신경근촉진법은 운동 단위가 최대한 활성화되도록 하는 운동 치료 방법으로 ${ }^{14}$ 고유수용성감각을 촉진 및 유도하여 효 율적인 기능적 움직임을 통하여 하지 근력 강화에 도움을 줄 수 있는 방법이라 사료된다. 본 연구에서 집단 간 균형 능력을 비교한 결과 대 조군에 비해 수중고유수용성신경근촉진법 패턴 운동을 실시한 실 험군에서 유의한 향상을 보였다. Song과 $\mathrm{Kim}^{31}$ 의 연구에서 고유수용 성신경근촉진법 패턴을 응용한 수중운동이 균형 능력 증진에 효과 적인 것으로 나타났으며 Kim과 Lee ${ }^{32}$ 는 수중에서 고유수용성신경근 촉진법 하지 패턴을 정상인에게 실시한 결과 균형 능력이 향상된 결 과를 얻었으며 이러한 선행 연구 결과는 본 연구 결과를 지지해 줄수 있다. 수중고유수용성신경근촉진법 패턴 운동은 ${ }^{32}$ 물속에서 부력에 의해 신체가 가볍게 느껴지고 관절에 부하가 적으며 물에 대한 저항 력을 제공하여 하지 근력 강화에도 긍정적인 영향을 미치기 때문에 균형 증진에 도움을 줄수 있다. ${ }^{33}$ 또한 수중고유수용성신경근촉진법 패턴 운동은 신경 말단으로부터 인대와 근육, 관절, 관절 주머니 및 피부에 위치하는 고유수용성 감각 수용기에 정보가 입력되어 근육 과 관절의 움직임 비율에 대한 정보를 제공함으로써 정상적임 움직 임을 유발하여 ${ }^{34}$ 자세 조절 및 균형 능력이 향상된 것으로 사료된다. 물의 특성 중 하나인 점성 저항은 수중에서 동작이 빠르고 커질수록 더 큰 저항이 발생되며 동작이 느리고 작을수록 저항은 작아지며 동 작 속도에 따라 저항 운동이 될 수 있고 능동 보조 운동이 될 수 있으 며 33,35 이러한 결과는 뇌졸중 환자의 균형 능력 향상에 긍정적인 영향 을주었다고할수 있다.

본 연구에서 만성 뇌졸중 환자의 보행 능력을 평가하기 위하여 $10 \mathrm{~m}$ 보행 검사를 실시하였으며 실험군과 대조군 모두 실험 전, 후 $10 \mathrm{~m}$ 보 행 검사에서 유의한 향상을 보였으며 집단 간 비교에서 대조군 보다 수중고유수용성신경근촉진법 패턴 운동을 적용한 실험군에서 유의 한 향상을 보였다. Sharma과 Kaur ${ }^{29}$ 은 골반 패턴을 이용한 고유수용 성신경근촉진법 안정화 운동이 만성 뇌졸중 환자의 보행 능력 향상 을 나타내었고 Mirek 등 ${ }^{6}$ 은 고유수용성신경근촉진법을 헌팅톤병 환 자에게 적용한 결과 보행 능력을 향상시켰다고 보고하였으며 선행 
연구와 대상자와 운동 방법에 다소 차이는 있지만 지지하는 결과를 도출 할 수 있었다. 본 연구에서 적용한 고유수용성신경근촉진법 패 턴 운동은 특유의 나선형 패턴을 이용하여 고유수용기를 자극하고 정상 반응을 촉진하고 등척성 수축을 일으켜 안정성과 자세 동요를 줄여 기능적인 보행 능력 향상에 긍정적인 영향을 주었다고 볼 수 있 다. $\operatorname{Kim}$ 등 $^{23}$ 은 수중에서 협응 움직임을 이용한 고유수용성신경근촉 진법 패턴 운동이 뇌졸중 환자의 보행 능력 향상에 긍정적인 영향을 미친다고 보고하였으며 $\operatorname{Kim}$ 등 37 은 수중에서 이중과제 운동이 지상 에서 이중과제 운동 보다 뇌졸중 환자의 보행 능력 향상에 효과적이 라고 하였으며 운동 방법에는 차이는 있지만 다양한 수중 환경에서 운동을 통한 연구 결과는 본 연구 결과와 유사하게 나타났다. 수중 환경은 중력의 영향을 감소시켜 관절의 움직임 향상과 다양한 형태 의 저항을 제공하여 근력과 감각 되먹임(sensory feedback) 증가에 긍 정적인 효과가 있다고 보고하였다. ${ }^{38}$ 또한 부력이라는 물의 특성에 의 해 중력이 감소되어 사용이 제한된 근육과 관절에 부담을 덜어주고 작은 힘으로 움직임이 가능하게 되고 이러한 움직임이 근육들을 자 극하여 보행에 사용되는 근육들을 활성화시켜 ${ }^{39}$ 보행 능력에 향상을 보인 것으로 생각된다. 또한 수중고유수용성신경근촉진법 패턴 운 동 시 물 자체가 저항으로 작용 할 수 있기 때문에 하지 근력 향상에 도움을 주어 보행 능력도 향상된 것으로 사료된다.

본 연구에서 만성 뇌졸중 환자의 우울 정도 평가하기 위하여 Beck 우울 척도 검사를 실시하였으며 실험군과 대조군 모두 실험 전 후 유 의한 향상을 보였으며 집단 간 비교에서 대조군 보다 수중고유수용 성신경근촉진법 패턴 운동을 적용한 실험군에서 유의한 향상을 보 였다. 뇌졸중으로 진단 받은 환자를 대상으로 비마비측 하지와 고유 수용성신경근촉진법 패턴을 적용하여 교차 훈련을 실시한 결과 우 울감에 좋은 영향을 미친다고 보고한 Song ${ }^{40}$ 의 연구와 유사한 결과 를 보였다. 이러한 결과 고유수용성신경근촉진법 패턴 운동은 신체 적인 기능 향상뿐만 아니라 우울이라는 심리적인 요인 향상에 효과 가 있음을 알 수 있다. Kim 등느는 수중운동을 뇌졸중 환자를 대상으 로 실시하였고 우울증 간이 선별 검사 도구를 이용하여 우울 정도를 측정한 결과 수중운동을 실시한 실험군에서 유의한 차이를 보였으 며 본 연구 결과와 일치하였다. Yohannes와 Caton ${ }^{41}$ 은 퇴행성 무릎관 절염 환자의 우울증 치료에 있어 지상 보다 수중에서 재활치료가 짧 은 시간 내에 우울 증상이 감소하였다고 보고하였으며 본 연구의 운 동 방법과 대상자 선정에 차이는 있지만 연구 결과는 유사하게 나타 났다. 이와 같이 선행 연구의 결과들이 본 연구 결과를 지지 할 수 있 으며 수중에서 운동 시 우울 예방뿐만 아니라 삶의 질 향상에도 도 움이 될 것으로 생각된다. 운동과 오락을 함께 할 수 있는 수중운동 은 뇌졸중 환자들의 과 긴장성과 두려움을 줄일 수 있으며 42 긍정적 인 신체상 확립과 사기를 증진 시키고 ${ }^{43}$ 심리적으로 긍정적인 도움을
줄 수 있을 것으로 사료된다. 이상의 연구 결과를 볼 때 수중고유수 용성신경근촉진법 패턴 운동은 만성 뇌졸중 환자의 우울과 같은 심 리적 요인에도 효과가 있음을 확인 할 수 있다. 따라서 본 연구를 종 합해 보면 만성 뇌졸중 환자에게 수중고유수용성신경근촉진법 패 턴 운동을 실시한 결과 균형과 보행 능력이 향상되었고 우울 같은 심 리적 요인은 감소되어 만성 뇌졸중 환자에게 효과적인 운동 방법으 로 제시 될수있다.

본 연구의 제한 점은 지역적 제한과 비교적 적은 수를 대상으로 연 구를 실시하였기 때문에 모든 만성 뇌졸중 환자에게 일반화하여 해 석하기에는 어려움이 있고 본 연구는 6주간 실험으로 종료되었기 때 문에 효과가 어느 정도 지속되었는지 추적 조사를 실시하지 못하였 다. 추후에는 제한 점을 보완하여 더 많은 대상자를 선택하여 연구가 이루어져야 할 것이다. 따라서 본 연구 결과에 따라 수중고유수용성 신경근촉진법 패턴 운동이 만성 뇌졸중 환자의 균형과 보행 및 우울 개선에 효과가 있음을 확인 할 수 있으며 이러한 결과를 바탕으로 만 성 뇌졸중 환자의 신체적 기능과 심리적 기능 회복이 어려운 환자에 게 균형과 보행 및 우울 개선에 도움을 줄 수 있는 운동으로 적용 될 수 있을 것으로 사료된다.

\section{REFERENCE}

1. Prange GB, Jannink MJ, Groothuis-Oudshoorn CG et al. Systematic review of the effect of robot-aided therapy on recovery of the hemiparetic arm after stroke. J Rehabil Res Dev. 2006;43(2):171-84.

2. Smania N, Picelli A, Gandolfi M et al. Rehabilitation of sensorimotor integration deficits in balance impairment of patients with stroke hemiparesis: a before/after pilot study. Neurol Sci. 2008;29(5):313-9.

3. Duncan PW, Samsa GP, Weinberger M et al. Health status of individuals with mild stroke. Stroke. 1997;28(4):740-5.

4. Wade DT, Wood VA, Hewer RL. Recovery after stroke-the first 3 months. J Neurol Neurosurg Psychiatry. 1985;48(1):7-13.

5. Bergamin M, Gobbo S, Zanotto T et al. Influence of age on postural sway during different dual-task conditions. Front Aging Neurosci. 2014;22(6): $1-7$.

6. Ikai T, Kamikubo T, Takehara I et al. Dynamic postural control in patients with hemiparesis. Am J Phys Med Rehabil. 2003;82(6):463-9.

7. Horstman AM, Beltman MJ, Gerrits KH et al. Intrinsic muscle strength and voluntary activation of both lower limbs and functional performance after stroke. Clin Physiol Funct Imaging. 2008;28(4):251-61.

8. Tyson SF, Hanley M, Chillala J et al. Balance disability after stroke. Phys Ther. 2006;86(1):30-8.

9. Kelly J, Hunt BJ, Lewis RR et al. Anticoagulation or inferior vena cava filter placement for patients with primary intracerebral hemorrhage developing venous thromboembolism? Stroke. 2003;34(12):2999-3005.

10. Bohannon RW, Horton MG, Wikholm JB. Importance of four variables of walking to patients with stroke. Int J Rehabil Res. 1991;14(3):246-50.

11. Roth EJ, Lovell L, Harvey RL et al. Incidence of and risk factors for medi- 
cal complications during stroke rehabilitation. Stroke. 2001;32(2):523-9.

12. Klein DA, William JS, Wayne TP et al. PNF training and physical function in assisted-living older adults. J Aging Phys Act. 2002;10(4):476-88.

13. Andersen LL, Magnusson SP, Nielsen M et al. Neuromuscular activation in conventional therapeutic exercises and heavy resistance exercises: implications for rehabilitation. Phys Ther. 2006;86(5):683-97.

14. Kofotolis ND, Kellis E. Cross-training effects of a proprioceptive neuromuscular facilitation exercise programme on knee musculature. Phys Ther Sport. 2007;8(3):109-16.

15. Lim CG. The Effects of proprioceptive neuromuscular facilitation (PNF) pattern exercise using the sprinter and the skater on balance and gait function in the stroke patients. J Kor Soc Phys Ther 2014;26(4):249-56.

16. Kim CH, Kim YN. Effects of proprioceptive neuromuscular facilitation and treadmill training on the balance and walking ability of stroke patients. J Kor Phys Ther 2018;30(3):79-83.

17. Matsumoto S, Uema T, Ikeda K et al. Effect of underwater exercise on lower-extremity function and quality of life in post-stroke patients: a pilot controlled clinical trial. J Altern Complement Med. 2016;22(8):63541.

18. Masumoto K, Shono T, Hotta N et al. Muscle activation, cardiorespiratory response, and rating of perceived exertion in older subjects while walking in water and on dry land. J Electromyogr Kinesiol. 2008;18(4): 581-90.

19. Clément G, Gurfinkel VS, Lestienne F et al. Adaptation of postural control to weightlessness. Exp Brain Res, 1984;57(1):61-72.

20. Choi SJ, Yoon SW. The effect of aquatic rotation exercise on balance maintenance. J Kor Soc Phys Ther 2010;22(1):27-32.

21. Kim SH, Lee DK, Kim EK. Effect of aquatic exercise on balance and depression of stroke patients. J Kor Soc Phys Ther 2014;26(2):104-9.

22. Kim EK, Lee DK, Kim YM. Effects of aquatic PNF lower extremity patterns on balance and ADL of stroke patients. J Phys Ther Sci. 2015;27(1):213-5.

23. Kim K, Lee DK, Jung SI. Effect of coordination movement using the PNF pattern underwater on the balance and gait of stroke patients. J Phys Ther Sci. 2015;27(12):3699-701.

24. Berg KO, Wood-Dauphinee SL, Williams JI et al. Measuring balance in the elderly: validation of an instrument. Can J Public Health. 1992;83(2): 7-11.

25. Dean CM, Richards CL, Malouin F. Task-related circuit training improves performance of locomotor tasks in chronic stroke: a randomized, controlled pilot trial. Arch Phys Med Rehabil. 2000;81(4):409-17.

26. Hanh HM, Yum TH, Shin YW et al. A Standardization Study of Beck Depression Inventory in Korea. Psychiatry Investig. 1986;25(3):487-500.

27. Geiger RA, Allen JB, O'Keefe J et al. Balance and mobility following stroke: effects of physical therapy interventions with and without biofeedback/forceplate training. Phys Ther. 2001;81(4):995-1005.

28. Park SE, Min KO, Lee SB et al. Effect of eye movements and proprioceptive neuromuscular facilitation on balance and head alignment in stroke patients with neglect syndrome. J Phys Ther Sci. 2016;28(2):596-601.

29. Sharma V, Kaur J. Effect of core strengthening with pelvic proprioceptive neuromuscular facilitation on trunk, balance, gait, and function in chronic stroke. J Exerc Rehabil. 2017;13(2):200-5.

30. Toulotte C, Fabre C, Dangremont B et al. Effects of physical training on the physical capacity of frail, demented patients with a history of falling: a randomised controlled trial. Age Ageing. 2003;32(1):67-73.

31. Song JM, Kim SM. The effect of aquatic exercise applied PNF patterns on body composition and balance performance in stroke patients. J. of the Korean Proprioceptive Neuromuscular Facilitation Association. 2008; 6(2):1-10.

32. Kim YN, Lee DK. Comparison between aquatic and ground environments of rhythmic initiation for postural control. J Phys Ther Sci, 2012; 24(12):1269-71.

33. Gusi N, Tomas-Carus P, Häkkinen A et al. Exercise in waist-high warm water decreases pain and improves health-related quality of life and strength in the lower extremities in women with fibromyalgia. Arthritis Rheum. 2006;55(1):66-73.

34. Carpenter JE, Blasier RB, Pellizzon GG. The effects of muscle fatigue on shoulder joint position sense. Am J Sports Med. 1998;26(2):262-5.

35. Wang TJ, Belza B, Elaine Thompson F et al. Effects of aquatic exercise on flexibility, strength and aerobic fitness in adults with osteoarthritis of the hip or knee. J Adv Nurs. 2007;57(2):141-52.

36. Mirek E, Filip M, Banaszkiewicz K et al. The effects of physiotherapy with PNF concept on gait and balance of patients with Huntington's disease-pilot study. Neurol Neurochir Pol. 2015;49(6):354-7.

37. Kim K, Lee DK, Kim EK. Effect of aquatic dual-task training on balance and gait in stroke patients. J Phys Ther Sci. 2016;28(7):2044-7.

38. Arnold CM, Busch AJ, Schachter CL et al. A randomized clinical trial of aquatic versus land exercise to improve balance, function, and quality of life in older women with osteoporosis. Physiother Can. 2008;60(4):296306.

39. Volaklis KA, Spassis AT, Tokmakidis SP. Land versus water exercise in patients with coronary artery disease: effects on body composition, blood lipids, and physical fitness. Am Heart J. 2007;154(3):560-6.

40. Song GB. Effects of indirect cross training on strengthening, balance, gait and depression in patients with stroke. Daegu University. Dissertation of Doctorate Degree. 2015.

41. Yohannes AM, Caton S. Management of depression in older people with osteoarthritis: A systematic review. Aging Ment Health. 2010;14(6):63751.

42. Jung T, Lee D, Charalambous $\mathrm{C}$ et al. The influence of applying additional weight to the affected leg on gait patterns during aquatic treadmill walking in people poststroke. Arch Phys Med Rehabil. 2010;91(1):12936.

43. Bherer L, Erickson KI, Liu-Ambrose T. A review of the effects of physical activity and exercise on cognitive and brain functions in older adults. J Aging Res. 2013:1-8. 